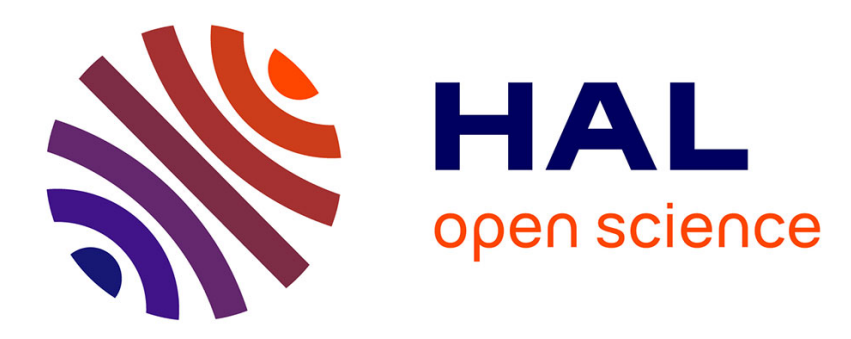

\title{
Protein-Protein Interaction: Tandem Affinity Purification in Bacteria
}

\author{
Julie Viala, Emmanuelle Bouveret
}

\section{To cite this version:}

Julie Viala, Emmanuelle Bouveret. Protein-Protein Interaction: Tandem Affinity Purification in Bacteria. Bacterial Protein Secretion Systems Methods and Protocols, 2017, Methods in Molecular Biology. hal-01788459

\section{HAL Id: hal-01788459 \\ https://hal.science/hal-01788459}

Submitted on 9 May 2018

HAL is a multi-disciplinary open access archive for the deposit and dissemination of scientific research documents, whether they are published or not. The documents may come from teaching and research institutions in France or abroad, or from public or private research centers.
L'archive ouverte pluridisciplinaire HAL, est destinée au dépôt et à la diffusion de documents scientifiques de niveau recherche, publiés ou non, émanant des établissements d'enseignement et de recherche français ou étrangers, des laboratoires publics ou privés. 


\section{Protein-protein interaction: Tandem Affinity Purification in bacteria}

2 Julie P.M. Viala and Emmanuelle Bouveret

3

4 Aix-Marseille University - CNRS - UMR7255 - Institut de Microbiologie de la Méditerranée,

5 Laboratoire d'Ingénierie des Systèmes Macromoléculaires, 31 Chemin Joseph Aiguier, 13009

6 Marseille, FRANCE

7

8 Correspondence: jviala@imm.cnrs.fr

9 Running head: TAP in bacteria 


\section{Summary}

12 The discovery of protein-protein interaction networks can unveil protein complex(es) forming 13 cellular machinerie(s) or can reveal component proteins of a specific cellular pathway. 14 Deciphering protein-protein interaction networks therefore participates to a better 15 understanding of how the cell functions. Here, we describe the protocol to perform Tandem 16 Affinity Purification (TAP) in bacteria that enables the identification of the partners of a bait 17 protein under native conditions. This method consists in two sequential steps of affinity 18 purification, using two different tags. For that purpose, the bait protein is translationally fused 19 to the TAP-tag, which consists in a calmodulin binding peptide (CBP) and two IgG binding 20 domains of Staphylococcus aureus protein A (ProtA) that are separated by the Tobacco Etch

21 Virus (TEV) protease cleavage site. After the first round of purification based on the binding 22 of ProtA to IgG coated beads, TEV protease cleavage releases CBP-tagged bait-protein along 23 with its partnersfor a second round of purification on calmodulin affinity resin and leaves 24 behind protein contaminants bound to IgG. Creating the TAP-tag translational fusion at the 25 chromosomal locus allows detection of protein interactions occurring in physiological 26 conditions.

\section{Keywords}

29 Protein-protein interaction, protein complex, affinity purification, TAP, CBP, ProtA, TEV, 30 E. coli, Salmonella 


\section{Introduction}

34 At the end of the nineties, mass spectrometry combined with genome sequencing rendered possible the rapid and systematic identification of all the proteins present in a purified sample. However, a protocol amenable to standardized and systematic purification of protein complexes without any prior knowledge was missing. In 1999, the laboratory of B. Séraphin in EMBL proposed such a generic procedure for the identification of protein complexes in yeast [1]. This permitted the subsequent description of the full interactome of yeast $[2,3]$. This method has since been used in a variety of organisms. We have first described its use in bacteria [4], and it was soon after used to obtain the first interactome of E. coli [5].

One general principle of the TAP method is to use 2 successive steps of affinity purification to lower as much as possible the amount of contaminants, together with an elution preserving the interactions (without changing much the buffer chemical properties) between these 2 steps. Specifically, the original TAP tag consists of 2 repeats of the IgG binding domain of Protein A from Staphylococcus aureus, and a Calmodulin Binding Peptide, separated by a TEV protease cleavage site (Fig. 1). However, it has to be noted that any combination of affinity tags is potentially usable. Published examples are the GS-TAP (Protein G and Strep tag), the SPA tag (CBP and 3Flag), the SF-TAP (Strep-tag II and Flag tag), or the HB tag (6Histidine and Biotin) (see [6] for specific references). The second general principle of the TAP procedure is to use physiological expression of the recombinant tagged protein. This needs to be adapted to each organism of interest. For E. coli and closely related bacteria, Lambda Red based recombination [7] combined with specific dedicated SPA and TAP cassettes [8], makes it very easy to introduce the tag at the 3' extremity of the gene on the chromosome to obtain the physiological production of a recombinant protein tagged at 
its C-terminus (Fig. 2). If more convenient, however, TAP tag translational fusion can also be expressed from a plasmid (Fig. 3).

We present here the TAP protocol that has been successfully used in our institute to purify protein complexes of E. coli, Salmonella, and Bacillus subtilis [4, 9, 10, and unpublished results]. A detailed protocol for the SPA purification has been published before [11]. In order to isolate a protein complex by TAP, a strain producing a recombinant bait protein tagged with the TAP tag has to be constructed first (Fig. 1, step 1). Then, a soluble extract is prepared from a sufficient volume of bacteria (about $500 \mathrm{ml}$ ). The complex is enriched by a first step of affinity chromatography on IgG beads (Fig. 1, step 5). After washes, TEV protease is added, which cleaves the specific site located between the CBP and ProtA domains, resulting in the elution of the specifically bound material (Fig. 1, step 6). This material is purified a second time by affinity of the CBP tag with Calmodulin beads (Fig. 1, step 7). After washes, the purified complex is eluted by adding EGTA that chelates the calcium required for the CBP/Calmodulin interaction (Fig. 1, step 8). The totality of the purified material is analyzed on SDS-PAGE. Bands detected by Coomassie blue or Silver staining are cut from the gel and analyzed by mass spectrometry.

This consists in the basic TAP procedure. It has to be noted that this procedure can be amenable to adaptation or improvements depending on the specific needs. For example, the extensive washes and the duration of the procedure only allows for the recovery of relatively stable complexes. For the detection of more transient or unstable interactions, a cross-linking procedure can be applied before purification [12]. This might be helpful also for the purification of membrane complexes, where modifications have to be made in the protocol for solubilization of the membranes [3]. Finally, it is possible to play with the 2 tags to gain information on the organization of the complexes. Indeed, in some cases, one bait protein might participate to the formation of several types of complexes. To purify one specific type 
81 of complex it is therefore possible to put the two tags on 2 distinct proteins that are both members of the desired type of complex (split tag method $[9,13]$ ). Alternatively, it is possible

to perform the subtraction method that consists in eliminating the unwanted complex(es)

84 during the first purification step, by leaving it, for example, on IgG beads thanks to a partner

85 protein of the bait that belongs to the unwanted complex and bears a non cleavable protA tag.

86 The desired complex, made of untagged partner proteins, will elute with the bait after TEV 87 protease cleavage $[13,14]$.

To our knowledge, the TAP procedure has not been used so much for the characterization of secretion systems in bacteria, certainly due to the difficulty of working with integral envelope components. However, it has proved to be powerful to identify the target of effectors of Legionella T4SS or Pseudomonas T6SS in eukaryotic host cells $[15,16]$.

92 In addition, as mentioned above, it is amenable to several improvements that might permit to 93 identify unsuspected partners of the secretion machineries in the bacterium.

\section{Materials}

2.1 Media, stock solutions and reagents

97 1. 2YT: $16 \mathrm{~g}$ Yeast Extract, $10 \mathrm{~g}$ Tryptone, $10 \mathrm{~g} \mathrm{NaCl}$, make up to $1 \mathrm{~L}$ with distilled 98 water. Autoclave and store at room temperature.

99 2. LB: $5 \mathrm{~g}$ Yeast Extract, $10 \mathrm{~g}$ Bactotryptone, $10 \mathrm{~g} \mathrm{NaCl}$, make up to $1 \mathrm{~L}$ with distilled 100 water. Autoclave and store at room temperature.

101 3. PBS: $8 \mathrm{~g} \mathrm{NaCl}, 0.2 \mathrm{~g} \mathrm{KCl}, 0.2 \mathrm{~g} \mathrm{KH}_{2} \mathrm{PO}_{4}, 2.9 \mathrm{~g} \mathrm{Na}_{2} \mathrm{HPO}_{4}$, make up to $1 \mathrm{~L}$ with 102 distilled water. Autoclave and store at room temperature. 
1034 4. $1 \mathrm{M}$ Tris $\mathrm{pH} 8$ stock solution: Dissolve $121 \mathrm{~g}$ of Tris base in $800 \mathrm{ml}$ of distilled water,

104 make up to $1 \mathrm{~L}$ with distilled water once the $\mathrm{pH}$ has been adjusted to 8 with $\mathrm{HCl}$. Autoclave 105 and store at room temperature.

1065 5. $5 \mathrm{M} \mathrm{NaCl}$ stock solution: Dissolve $292 \mathrm{~g} \mathrm{NaCl}$ in $1 \mathrm{~L}$ of distilled water. Autoclave and 107 store at room temperature.

1086 6. $10 \%$ Nonidet P-40 (NP-40 or Igepal): Mix $10 \mathrm{ml} \mathrm{NP}-40$ to $90 \mathrm{ml}$ of distilled water, $1090.2 \mu \mathrm{m}$ filter and store at room temperature (note 1).

110 7. $0.5 \mathrm{M}$ EDTA $\left(\mathrm{C}_{10} \mathrm{H}_{14} \mathrm{~N}_{2} \mathrm{Na}_{2} \mathrm{O}_{8} \cdot 2 \mathrm{H}_{2} \mathrm{O}\right)$ : Dissolve $18.6 \mathrm{~g}$ of EDTA to $80 \mathrm{ml}$ of distilled 111 water, make up to $100 \mathrm{ml}$ with distilled water once the $\mathrm{pH}$ has been adjusted to 8 with $11210 \mathrm{~N} \mathrm{NaOH}$ (note 2). Autoclave and store at room temperature.

113 8. 1 M DTT: Dissolve $1.54 \mathrm{~g}$ in $10 \mathrm{ml}$ distilled water. Store at $-20^{\circ} \mathrm{C}$.

1149 9. $1 \mathrm{M}$ magnesium acetate $\left(\mathrm{Mg}\left(\mathrm{CH}_{3} \mathrm{COO}\right)_{2} .4 \mathrm{H}_{2} \mathrm{O}\right)$ : Dissolve $10.7 \mathrm{~g}$ magnesium acetate 115 in $50 \mathrm{ml}$ distilled water, $0.2 \mu \mathrm{m}$ filter and store at room temperature.

116 10. $1 \mathrm{M}$ imidazole: Dissolve $3.4 \mathrm{~g}$ imidazole to $50 \mathrm{ml}$ distilled water, $0.2 \mu \mathrm{m}$ filter and 117 store at $-20^{\circ} \mathrm{C}$.

118 11. $1 \mathrm{M} \mathrm{CaCl}_{2}$ : Dissolve $11.1 \mathrm{~g}$ to $100 \mathrm{ml}$ distilled water. Autoclave and store at room 119 temperature.

120 12. 1 M EGTA: Dissolve $19 \mathrm{~g}$ to $40 \mathrm{ml}$ distilled water, make up to $50 \mathrm{ml}$ with distilled 121 water once the $\mathrm{pH}$ has been adjusted to 8 with $10 \mathrm{~N} \mathrm{NaOH}$ (note 2), $0.2 \mu \mathrm{m}$ filter and store at $1224^{\circ} \mathrm{C}$.

123 13. 0.1 M PMSF: Dissolve $87.1 \mathrm{mg}$ PMSF to $5 \mathrm{ml}$ isopropanol. Prepare $1 \mathrm{ml}$ aliquots and 124 store at $-20^{\circ} \mathrm{C}$ (note 3$)$ 
125 14. $16 \mathrm{mg} / \mathrm{ml}$ sodium deoxycholate: Dissolve $160 \mathrm{mg}$ sodium deoxycholate to $10 \mathrm{ml}$ water

126 and $0.2 \mu \mathrm{m}$ filter. Store at room temperature.

$127 \quad 15 . \quad \beta$-mercaptoethanol (stock is at $14.3 \mathrm{M}$ )

128 16. Liquid Trichloroacetic acid (stock is $100 \%$ )

129 17. Acetone

$130 \quad 18 . \quad$ Ethanol

131 19. Peroxidase Anti-Peroxidase antibody (PAP) (Sigma, \# P1291)

132 20. $\quad$ AcTEV $^{\mathrm{TM}}$ protease (Invitrogen, \# 12575015)

133 21. IgG sepharose 6 fast flow (GE Healthcare, \# 17-0969-01)

134 22. Calmodulin affinity resin (Agilent, \# 214303)

135 23. Disposable chromatography columns (Bio-Rad, \# 7311550)

136

137

\subsection{Buffers}

138 1. Protein A binding buffer : $10 \mathrm{mM}$ Tris- $\mathrm{HCl} \mathrm{pH} 8,150 \mathrm{mM} \mathrm{NaCl}, 0.1 \% \mathrm{NP}-40$

139 Approximately $50 \mathrm{ml}$ will be required per sample per experiment.

140 Prepare $500 \mathrm{ml}$ containing $5 \mathrm{ml}$ of $1 \mathrm{M}$ Tris- $\mathrm{HCl} \mathrm{pH} 8,15 \mathrm{ml}$ of $5 \mathrm{M} \mathrm{NaCl}, 5 \mathrm{ml}$ of $14110 \% \mathrm{NP}-40$ and $475 \mathrm{ml}$ of distilled water. Store at $4^{\circ} \mathrm{C}$.

142 2. TEV cleavage buffer : $10 \mathrm{mM}$ Tris- $\mathrm{HCl} \mathrm{pH} 8, \quad 150 \mathrm{mM} \mathrm{NaCl}, \quad 0.1 \% \mathrm{NP}-40$, 1430.5 mM EDTA, 1 mM DTT 
144 Approximately $1.5 \mathrm{ml}$ will be required per sample per experiment.

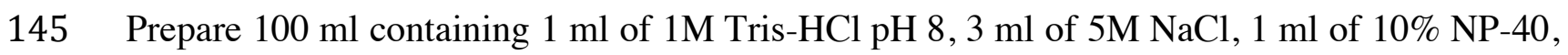
$146100 \mu 1$ of $0.5 \mathrm{M}$ EDTA, $100 \mu 1$ of $1 \mathrm{M}$ DTT (note 4) and $95 \mathrm{ml}$ of distilled water. Store at $4^{\circ} \mathrm{C}$.

147 3. Calmodulin binding buffer : $10 \mathrm{mM}$ Tris- $\mathrm{HCl} \mathrm{pH} 8,150 \mathrm{mM} \mathrm{NaCl}, 0.1 \%$ NP-40, $1481 \mathrm{mM}$ magnesium acetate, $1 \mathrm{mM}$ imidazole, $2 \mathrm{mM} \mathrm{CaCl} 2,10 \mathrm{mM} \beta$-mercaptoethanol

149 Approximately $40 \mathrm{ml}$ will be required per sample per experiment.

150 Prepare $500 \mathrm{ml}$ containing $5 \mathrm{ml}$ of $1 \mathrm{M}$ Tris- $\mathrm{HCl} \mathrm{pH} 8,15 \mathrm{ml}$ of $5 \mathrm{M} \mathrm{NaCl}, 5 \mathrm{ml}$ of $10 \% \mathrm{NP}-40$, $151500 \mu 1$ of $1 \mathrm{M}$ magnesium acetate, $500 \mu \mathrm{l}$ of $1 \mathrm{M}$ imidazole, $1 \mathrm{ml}$ of $1 \mathrm{M} \mathrm{CaCl}_{2}, 348.5 \mu 1$ of $15214.3 \mathrm{M} \beta$-mercaptoethanol (note 5) and $473 \mathrm{ml}$ of distilled water. Store at $4^{\circ} \mathrm{C}$.

153 4. Calmodulin elution buffer : $10 \mathrm{mM}$ Tris- $\mathrm{HCl} \mathrm{pH} 8,150 \mathrm{mM} \mathrm{NaCl}, 0.1 \%$ NP-40, $1541 \mathrm{mM}$ magnesium acetate, $1 \mathrm{mM}$ imidazole, $2 \mathrm{mM}$ EGTA, $10 \mathrm{mM} \beta$-mercaptoethanol

155 Approximately $1 \mathrm{ml}$ will be required per sample per experiment.

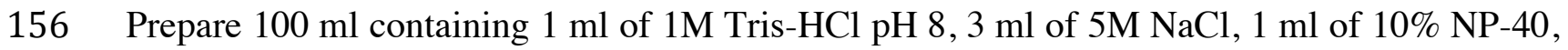
$157100 \mu \mathrm{l}$ of $1 \mathrm{M}$ magnesium acetate, $100 \mu \mathrm{l}$ of $1 \mathrm{M}$ imidazole, $200 \mu \mathrm{l}$ of $1 \mathrm{M}$ EGTA, 69,7 $\mu 1$ of $158 \quad 14.3 \mathrm{M} \beta$-mercaptoethanol (note 5) and $94.5 \mathrm{ml}$ of distilled water. Store at $4^{\circ} \mathrm{C}$.

159 5. TCA Washing Buffer: Mix $70 \mathrm{ml}$ acetone, $20 \mathrm{ml}$ ethanol, $5 \mathrm{ml} 1 \mathrm{M}$ Tris $\mathrm{pH} 8$ and $5 \mathrm{ml}$ 160 distilled water. Store at $4^{\circ} \mathrm{C}$.

163 1. Centrifuge tubes and rotor compatible with spinning volumes of $250 \mathrm{ml}, 10 \mathrm{ml}$ and $16450 \mathrm{ml}$, at approximately $5000 \mathrm{rpm}, 15000 \mathrm{rpm}$ and $6000 \mathrm{rpm}$, respectively. 
$1652 . \quad$ Sonicator, French press or Cell disruptor

$1663 . \quad$ Disposable chromatography columns of $10 \mathrm{ml}$

167 4. Wheel

168

169

\section{Methods}

170

3.1 Preamble

171

Construction of the TAP-taged protein translational fusion

172 A translational fusion between the protein of interest and TAP tag, either at the chromosomal

173 locus or on an appropriate plasmid has to be constructed. Translational fusion at the 174 chromosomal locus will allow a physiological expression, while constructing the translational 175 fusion on a plasmid may be more amenable.

176

A C-terminal TAP tag translational fusion can be introduced at the chromosomal locus

177 using the $\lambda$ red recombination system [7]. To prepare the appropriate PCR product, use pJL72

178 plasmid as template (this latter harbors a cassette made of the TAP tag and the kanamycine

179 resistance gene, Fig. 2A) [8], design a forward primer that contains, in the 5'-end, the 45

180 nucleotides that are immediately upstream the stop codon of the gene of interest, followed by

181 the sequence 5'-TCCATGGAAAAGAGAAG-3' (this sequence will hybrid to the CBP tag,

182 Fig. 2B) and design a reverse primer that contains at its 5 '-end the reverse complement 45

183 nucleotides that are immediately downstream the stop codon of the gene of interest, followed

184 by the sequence 5'-CATATGAATATCCTCCTTAG-3' (Fig. 2A). 
185 Alternatively, the sequence corresponding to the open reading frame of the gene of interest 186 can be cloned in the plasmid pEB587 [17] (Fig. 3A), which allows a N-terminal TAP tag

187 translational fusion (Fig. 3B) under the control of the PBAD arabinose inducible promoter.

188

189 Verifying the expression of the TAP-tag translational fusion by western blot

190 Prepare a cytoplasmic or a crude protein extract (note 6), load $10 \mu \mathrm{g}$ of protein extract (or 191 proteins corresponding to a bacterial sample of $0.3 \mathrm{OD}_{600}$ unit) on a SDS-PAGE and proceed 192 to transfer and western blot to verify production of the hybrid protein (note 7).

193 A one step western blot can be performed using PAP antibody (note 8) and using an 194 appropriate substrate to detect horseradish peroxidase activity. In our experience, the 195 detection of the tagged protein in crude extracts using this PAP antibody is mandatory for a 196 successful TAP purification.

197

198 3.2 Protein cytoplasmic extract

199 1. Day 1 - Inoculate $10 \mathrm{ml}$ of $2 \mathrm{YT}$ media with a bacterial colony and grow overnight at $20037^{\circ} \mathrm{C}$ with shaking (note 6).

201 2. Day 2 - Dilute culture 1:100 in $500 \mathrm{ml} \mathrm{LB}$ and grow $5 \mathrm{~h} 30$ at $37^{\circ} \mathrm{C}$ with shaking until $202 \mathrm{OD}_{600} \approx 2-3$.

2033 . Pellet bacteria by centrifugation $20 \min 5000 \mathrm{rpm}$ at $4^{\circ} \mathrm{C}$.

204 4. Wash once with cold PBS, transfer to 50ml centrifuge tubes, centrifuge again $10 \mathrm{~min}$ $2056000 \mathrm{rpm}$ at $4^{\circ} \mathrm{C}$, discard supernatant and freeze bacterial pellet with liquid nitrogen. 
206 Keep frozen bacterial pellet at $-80^{\circ} \mathrm{C}$ until you are ready to prepare cytosolic protein extract 207 and proceed to Tandem Affinity Purification.

2085 . Day 3 - Resuspend frozen bacterial pellet with $10 \mathrm{ml}$ of Protein A binding buffer 209 containing $0.5 \mathrm{mM}$ PMSF (note 3).

210 6. Use sonication, French Press or Cell disruptor to break bacterial cells (note 9).

211 7. Centrifuge $30 \mathrm{~min} 15000 \mathrm{rpm}$ at $4^{\circ} \mathrm{C}$ and save supernatant, which is the cytoplasmic 212 protein extract.

215 From here, carry out all procedures with gloves to avoid contamination of your sample(s)

216 with keratine.

217 1. Put $200 \mu 1$ of IgG sepharose beads in a disposable chromatography column and wash 218 by gravity with $5 \mathrm{ml}$ of Protein A binding buffer.

219 2. Binding of the Protein A tag to IgG sepharose beads. After washing the beads, close 220 the bottom of the chromatography column and, using a pipette, transfer $9 \mathrm{ml}$ of the 221 cytoplasmic protein extract. Close the top of the column and put on a wheel for 2 hours at $4^{\circ} \mathrm{C}$.

222 3. Remove first the top plug of the column and then the bottom one. Leave the unbound 223 material flow by gravity and discard.

224 4. Wash the IgG beads still in the column by gravity, with 3 times $10 \mathrm{ml}$ of Protein A 225 binding buffer. 
226 5. TEV protease cleavage. Close the bottom of the column, fill it with $1 \mathrm{ml}$ of TEV

227 cleavage buffer and 100 units of $\mathrm{AcTEV}^{\mathrm{TM}}$ protease. Close the top of the column and put on a

228 wheel at room temperature for one hour.

229 6. Remove the top and bottom plugs and recover elution by gravity. Add an additional $230200 \mu 1$ of TEV cleavage buffer in the column in order to recover as much material as possible 231 from the sides of column.

232 7. Add $3 \mathrm{ml}$ of calmodulin binding buffer and $3 \mu 1$ of $1 \mathrm{M} \mathrm{CaCl}_{2}$ (note 10) to the elution 233 fraction.

234 8. Binding by the CBP tag part on calmodulin affinity resin. In a new disposable 235 chromatography column, put $200 \mu 1$ of calmodulin affinity resin, and wash it with $5 \mathrm{ml}$ of 236 Calmodulin binding buffer. Then, close the bottom of column.

237 9. Add the $4.2 \mathrm{ml}$ elution fraction (obtained at steps 6 and 7). Close the top of column 238 and put on wheel for 1 hour at $4^{\circ} \mathrm{C}$.

239 10. Remove first the top plug of the column and then the bottom one. Leave the unbound 240 material to flow by gravity and discard.

241 11. Wash calmodulin affinity resin by gravity, with 3 times $10 \mathrm{ml}$ of calmodulin binding 242 buffer

243 12. Elution. Elute with 5 times $200 \mu 1$ of Calmodulin elution Buffer.

244 13. Pool fraction 2, 3 and 4 and proceed to TCA precipitation of elution fractions (1), 245 (pooled 2,3 and 4), and (5). 
248 1. To each of the eluted protein samples, add 1/100th of $16 \mathrm{mg} / \mathrm{ml}$ sodium deoxycholate. 249 Vortex and leave on ice $30 \mathrm{~min}$.

2502 2. Add TCA to $10 \%$ final. Vortex and leave on ice $30 \mathrm{~min}$.

2513 . Centrifuge $15 \mathrm{~min} 15000 \mathrm{rpm}$ at $4^{\circ} \mathrm{C}$.

252 4. Wash twice with TCA wash buffer.

2535 5. Leave the pellet to dry on bench and resuspend in $20 \mu 1$ protein loading buffer $1 \mathrm{x}$.

254

3.5 Analysis by SDS-PAGE and mass spectrometry

256 1. Load the totality of the samples on SDS-PAGE (note 11) and stain with Coomassie 257 Blue.

$2582 . \quad$ Unstained and then rince with distilled water.

2593 . Cuts bands to identify partner proteins by mass spectrometry (note 12).

260

261

\section{Notes}

262 Note 1: Gently agitate the solution for complete dissolution of NP-40 if necessary.

263 Note 2: EDTA and EGTA may not be soluble until $\mathrm{pH}$ had been adjusted to 8 with $26410 \mathrm{~N} \mathrm{NaOH}$. 
265 Note 3: PMSF cristallizes at $-20^{\circ} \mathrm{C}$, therefore heat PMSF aliquot to $37^{\circ} \mathrm{C}$ to redissolve $\mathrm{PMSF}$

266 before use. We use PMSF as generic protease inhibitor but protease inhibitor cocktail can be

267 used alternatively.

268 Note 4: Add DTT to the volume of buffer you will need when starting the experiment. DTT 269 is necessary for TEV activity.

270 Note 5: Add $\beta$-mercaptoethanol to the volume of buffer you will need when starting the 271 experiment.

272 Note 6: Also plan to prepare a protein extract of an untagged strain as negative control of the 273 experiment.

274 Note 7 : Translational TAP tag fusion adds $20 \mathrm{kDa}$ to the mass of the protein of interest;

$2753 \mathrm{kDa}$ corresponds to the CBP tag and $15 \mathrm{kDa}$ to the Protein A tag.

276 Note 8: Immunoglobulins will bind the protein A fragment of TAP tag.

277 Note 9: French Press or Cell disruptor might be more gentle to preserve protein complexes.

278 Note 10: Addition of extra $\mathrm{CaCl}_{2}$ is required to quench EDTA that was previously necessary 279 for TEV protease activity.

280 Note 11: Usually a 12\% SDS-PAGE allows visualization of low and high molecular weigh 281 proteins.

282 Note 12: Use one blade per band. 


\section{References}

285 1. Rigaut G, Shevchenko A, Rutz B, Wilm M, Mann M et al. (1999) A generic protein 286 purification method for protein complex characterization and proteome exploration. Nat $287 \quad$ Biotechnol 17: 1030-1032.

288 2. Gavin AC, Bosche M, Krause R, Grandi P, Marzioch M et al. (2002) Functional 289 organization of the yeast proteome by systematic analysis of protein complexes. Nature $290 \quad 415: 141-147$.

291 3. Gavin AC, Aloy P, Grandi P, Krause R, Boesche M et al. (2006) Proteome survey 292 reveals modularity of the yeast cell machinery. Nature 440: 631-636.

293 4. Gully D, Moinier D, Loiseau L, Bouveret E (2003) New partners of acyl carrier protein 294 detected in Escherichia coli by tandem affinity purification. FEBS Lett 548: 90-96.

295 5. Butland G, Peregrin-Alvarez JM, Li J, Yang W, Yang X et al. (2005) Interaction 296 network containing conserved and essential protein complexes in Escherichia coli. $297 \quad$ Nature 433: 531-537.

298 6. Collins MO, Choudhary JS (2008) Mapping multiprotein complexes by affinity 299 purification and mass spectrometry. Curr Opin Biotechnol 19: 324-330.

300 7. Datsenko KA, Wanner BL (2000) One-step inactivation of chromosomal genes in 301 Escherichia coli K-12 using PCR products. Proc Natl Acad Sci U S A 97: 6640-6645.

302 8. Zeghouf M, Li J, Butland G, Borkowska A, Canadien V et al. (2004) Sequential Peptide 303 Affinity (SPA) system for the identification of mammalian and bacterial protein 304 complexes. J Proteome Res 3: 463-468. 
305 9. Gully D, Bouveret E (2006) A protein network for phospholipid synthesis uncovered by a variant of the tandem affinity purification method in Escherichia coli. Proteomics 6: 282-293.

10. Pompeo F, Luciano J, Galinier A (2007) Interaction of GapA with HPr and its homologue, Crh: Novel levels of regulation of a key step of glycolysis in Bacillus subtilis? J Bacteriol 189: 1154-1157.

11. Babu M, Butl G, Pogoutse O, Li J, Greenblatt JF et al. (2009) Sequential Peptide Affinity Purification System for the Systematic Isolation and Identification of Protein Complexes from Escherichia coli. Methods Mol Biol 564: 373-400.

12. Stingl K, Schauer K, Ecobichon C, Labigne A, Lenormand P et al. (2008) In vivo interactome of Helicobacter pylori urease revealed by tandem affinity purification. Mol Cell Proteomics 7: 2429-2441.

13. Puig O, Caspary F, Rigaut G, Rutz B, Bouveret E et al. (2001) The tandem affinity purification (TAP) method: a general procedure of protein complex purification. Methods 24: 218-229.

14. Bouveret E, Rigaut G, Shevchenko A, Wilm M, Seraphin B (2000) A Sm-like protein complex that participates in mRNA degradation. EMBO J 19: 1661-1671.

15. So EC, Schroeder GN, Carson D, Mattheis C, Mousnier A et al. (2016) The Rabbinding Profiles of Bacterial Virulence Factors during Infection. J Biol Chem 291: $5832-5843$.

16. Sana TG, Baumann C, Merdes A, Soscia C, Rattei T et al. (2015) Internalization of Pseudomonas aeruginosa Strain PAO1 into Epithelial Cells Is Promoted by Interaction of a T6SS Effector with the Microtubule Network. MBio 6: e00712. 
328 17. Battesti A, Bouveret E (2008) Improvement of bacterial two-hybrid vectors for detection of fusion proteins and transfer to pBAD-tandem affinity purification, 330 calmodulin binding peptide, or 6-histidine tag vectors. Proteomics 8: 4768-4771. 


\section{Guidelines}

1. Construction

2. Check Expression of the TAP-tagged bait protein by Western blot with PAP antibody

3. Production

4. Cytoplasmic protein extract

5. Protein A binding

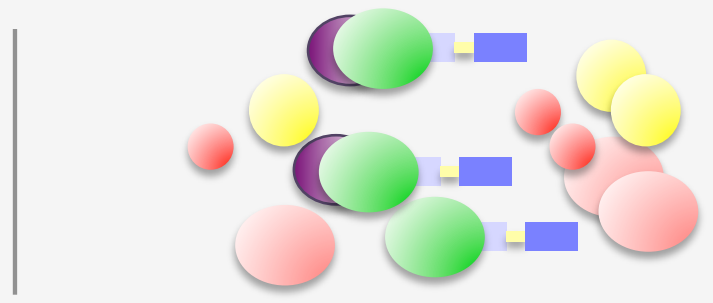

Add:

partner bait

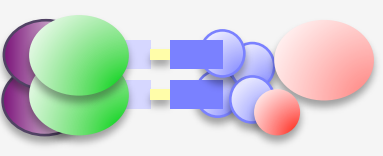

IgG beads

6. TEV cleavage

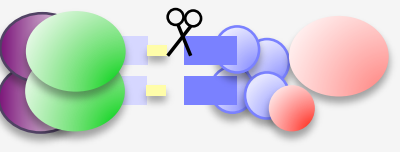

Q TEV protease

7. CBP binding

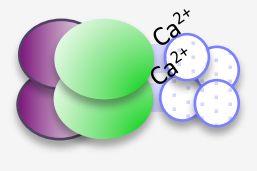

Calmodulin beads $\mathrm{Ca}^{2+}$

8. Elution + TCA precipitation
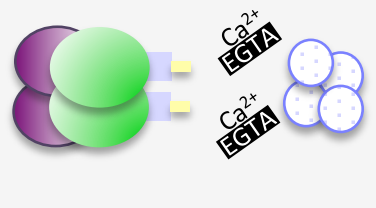

EGTA

9. SDS-PAGE and staining Cut band and analyze by Mass spectrometry

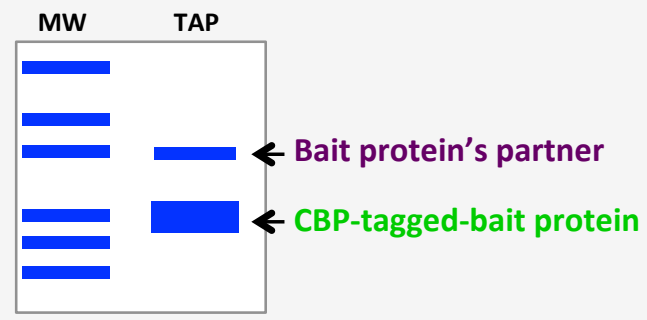

Fig. 1. Guidelines for the overall Tandem Affinity Purification procedure 


\section{Design primers}

A

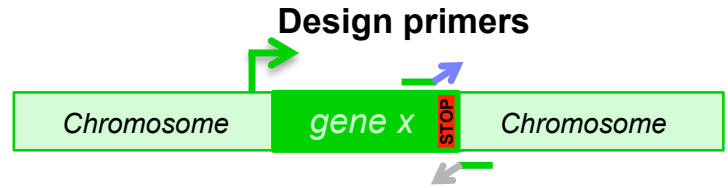

Amplify TAP tag cassette

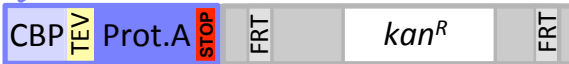

\section{Recombine at chromosomal locus with $\lambda$ Red system}

\begin{tabular}{|c|c|c|}
\hline Chromosome & ne $x$ & CBP豈Prot.A \\
\hline
\end{tabular}

B

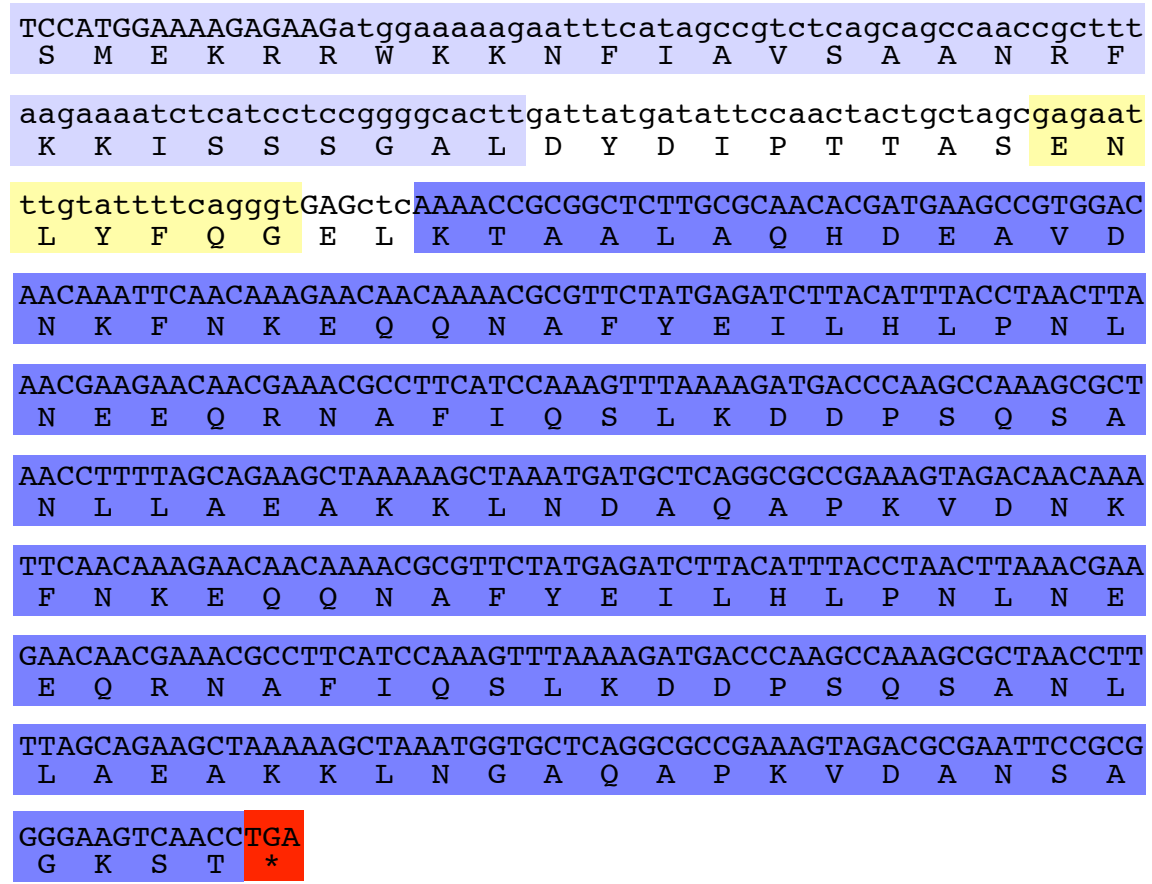

Fig 2. Scheme of the procedure for creation of a C-terminal TAP-tag translational fusion at the chromosomal locus (A) and the corresponding nucleotidic and protein TAP-tag sequences (B). CBP sequence is in clear purple; upper cases at the beginning of the nucleotidic $C B P$ sequence corresponds to the primer sequence mentioned in 3.1, TEV protease cleavage site is in yellow and Protein A sequence is in dark purple with the stop codon in red. 
A

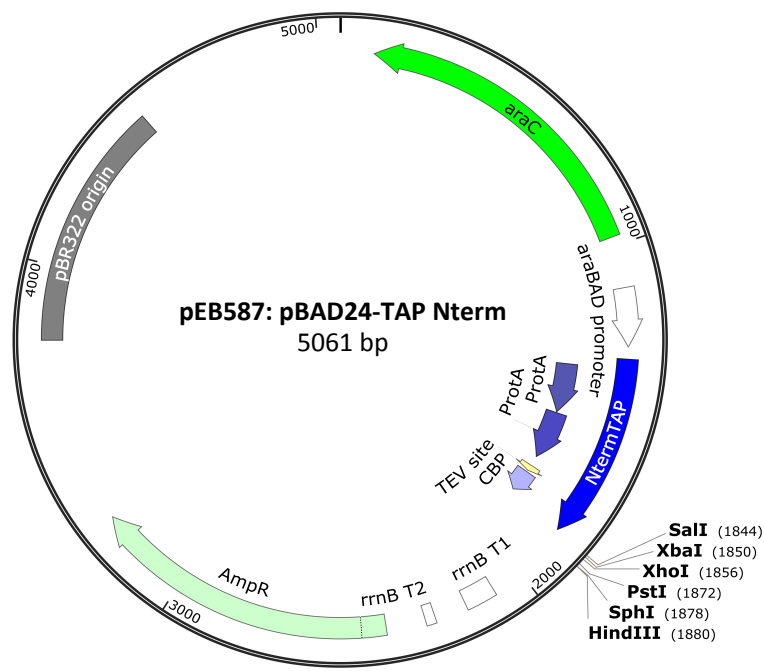

B

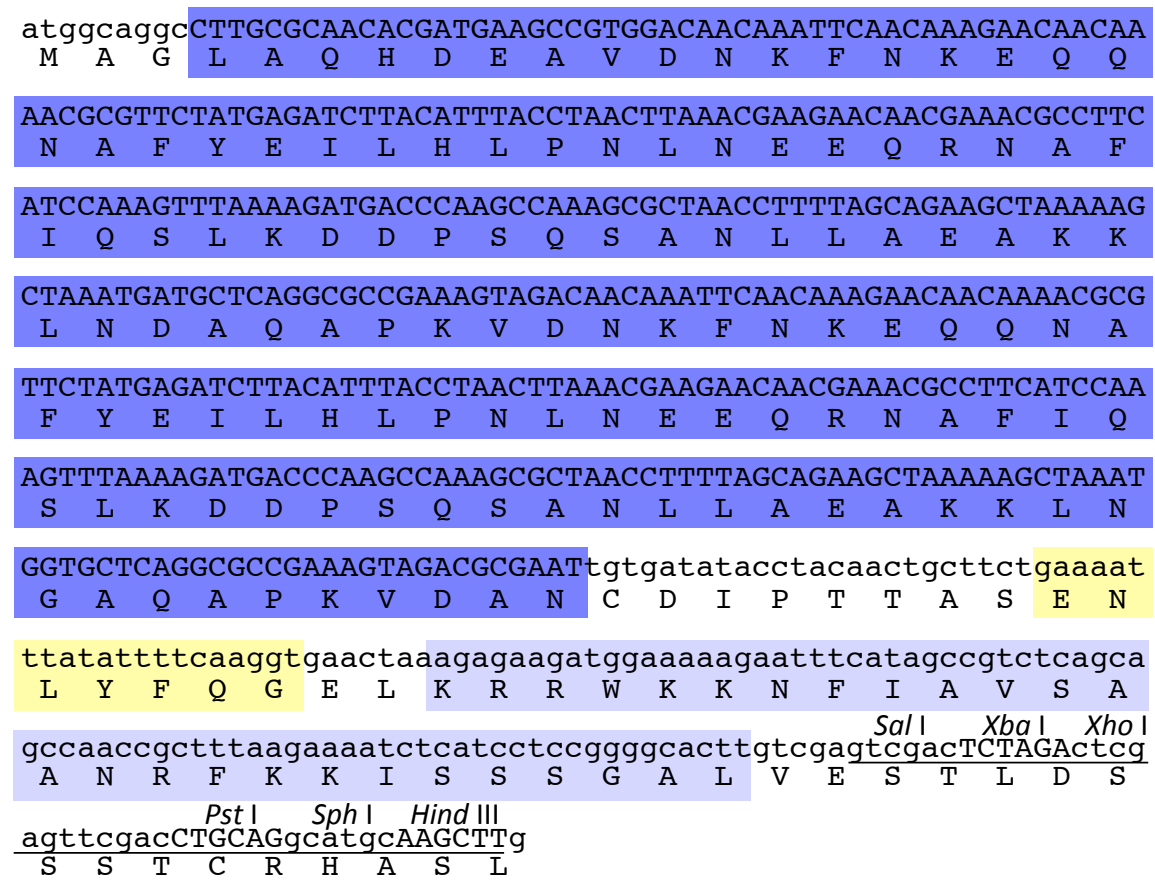

Fig 3. Map of plasmid pEB587 used to create a N-terminal TAP-tag translational fusion under the control of the $P_{B A D}$ arabinose inducible promoter $(A)$ and the corresponding nucleotidic and protein TAP-tag sequences (B). Protein A sequence is in dark purple, TEV protease cleavage site is in yellow, CBP sequence is in clear purple, the multicloning site is underlined and restrition enzyme sites are indicated. 